\title{
Effects of progesterone and anti-progesterone RU486 on ovarian $3 \beta$-hydroxysteroid dehydrogenase activity during ovulation in the gonadotrophin-primed immature rat
}

\author{
N. Tanaka, J. Iwamasa, K. Matsuura and H. Okamura \\ Department of Obstetrics and Gynecology, Kumamoto University Medical School, Kumamoto 860, \\ Japan
}

\begin{abstract}
The effects of progesterone and RU486, a synthetic anti-progesterone, on ovarian $3 \beta$-hydroxysteroid dehydrogenase ( $3 \beta$-HSD) activity, a key enzyme of progesterone production, were studied during ovulation in immature 22-day-old rats primed with pregnant mares' serum gonadotrophin (PMSG) and human chorionic gonadotrophin (hCG). Ovarian $3 \beta$-HSD activities had increased significantly $4 \mathrm{~h}$ after hCG injection. These increases were inhibited at 4 and $6 \mathrm{~h}$ after hCG when $20 \mathrm{mg}$ RU486 $\mathrm{kg}^{-1}$ was administered $2 \mathrm{~h}$ before hCG. However, RU486 had no influence on the activity of $3 \beta$-HSD when administered at the same time as hCG injection. A histochemical study revealed that $3 \beta$-HSD activities in the granulosa cell layer, but not in the theca cell layer, were inhibited when RU486 was given $2 \mathrm{~h}$ before hCG. Serum progesterone concentrations, but not oestradiol concentrations, were significantly suppressed by RU 486 treatment 4 and $6 \mathrm{~h}$ after hCG. The effect of progesterone on ovarian $3 \beta$-HSD activity was tested by administering graded doses of progesterone exogenously to rats $2 \mathrm{~h}$ before hCG injection. Ovarian $3 \beta$-HSD activity was increased in a dose-dependent manner, and more than $20 \mathrm{mg}$ progesterone $\mathrm{kg}^{-1}$ significantly stimulated the activity. Although $10 \mathrm{mg}$ progesterone $\mathrm{kg}^{-1}$ did not stimulate ovarian $3 \beta-\mathrm{HSD}$ activities, the RU486-inhibited activities were recovered by the concomitant administration of $10 \mathrm{mg}$ progesterone $\mathrm{kg}^{-1}$ with RU486. These results indicate that ovarian $3 \beta$-HSD activity depends on progesterone concentrations, and suggest an autocrine regulation of progesterone production during ovulation in immature rat ovaries stimulated with PMSG and hCG.
\end{abstract}

\section{Introduction}

Although ovarian steroidogenesis is primarily controlled by pituitary gonadotrophins, the possibility of autocrine and paracrine controls of steroid production in the ovary has been debated. The hypothesis of autocrine regulation of ovarian progesterone secretion is based on experiments in hypophysectomized animals and granulosa cell culture. Removal of the pituitary just after ovulation has no influence on the pattern of progesterone secretion and the function of the corpus luteum (Smith et al., 1975). A synthetic progestin, R5020, stimulates progesterone secretion in cultured granulosa cells (Fanjul et al., 1983). 17 $\beta$-Hydroxy-11 $\beta$-(4-dimethylamino-phenyl-1)-17 $\alpha$ (propynyl-1)-estra-4,9-diene-3-one (RU486), a synthetic antiprogesterone without agonist effect (Herrman et al., 1982; Healy et al., 1983), decreases progesterone secretion from cultured human granulosa cell (Dimattina, 1986).

It is known that RU486 can inhibit ovulation. Rao and Mahesh (1986) suggested that RU486 inhibits ovulation through an antagonism of the action of progesterone on the preovulatory surge of gonadotrophins in rats. We have previously demonstrated that progesterone production changed significantly during the first $4 \mathrm{~h}$ of the ovulatory process after hCG injection, that this increase plays an important role on ovulation by regulating proteolytic enzyme activities, and that RU486 inhibits ovulation through an antagonism of the action of progesterone on proteolytic enzyme activities in PMSG/ hCG-primed immature rats (Iwamasa et al., 1992). In this study, autocrine regulation of progesterone production during ovulation was examined by investigating biochemically and histochemically ovarian $3 \beta$-hydroxysteroid dehydrogenase ( $3 \beta$-HSD, EC 1.1.1.51) activity, which is responsible for the conversion of pregnenolone to progesterone as well as other $\Delta^{5}$ to $\Delta^{4}$ steroids, in rats treated with RU486 or progesterone in vivo.

\section{Materials and Methods}

\section{PMSG/hCG-primed rat model}

Immature Wistar rats (22 days old) received an s.c. injection at 09:00 h of 10 iu pregnant mares' serum gonadotrophin (PMSG; 


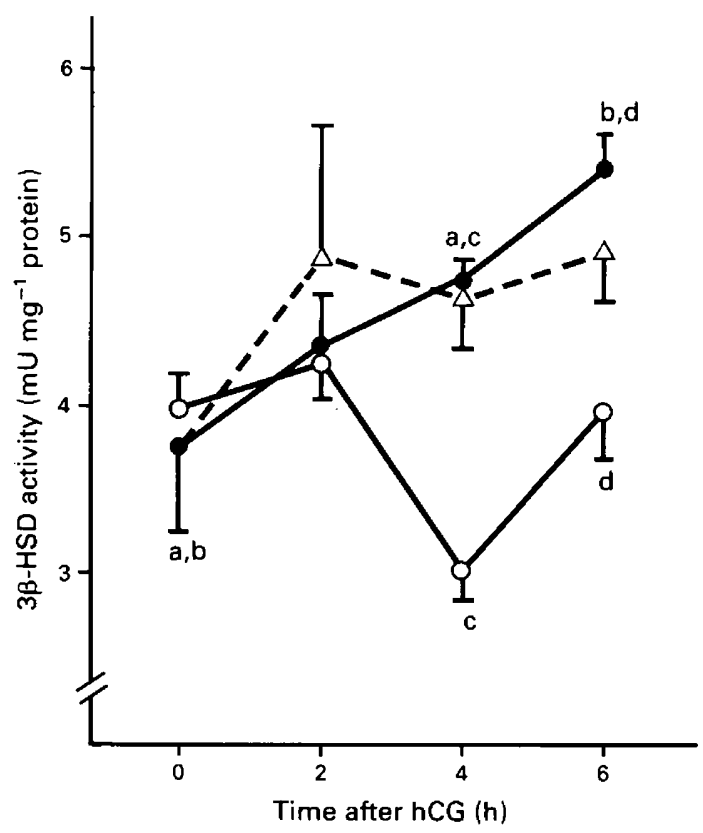

Fig. 1. Effect of RU486 on ovarian $3 \beta$-hydroxysteroid dehydrogenase (3ß-HSD) activity. Control (- RU486, $20 \mathrm{mg} \mathrm{kg}^{-1}$, was given $(O-O) 2 \mathrm{~h}$ before $\mathrm{hCG}$ injection or $(\triangle---\triangle)$ at the same time as hCG injection. Points with the same letter differ significantly (a: $P<0.05 ; b, c, d: P<0.01)$. Each point represents the mean \pm SEM from six rats.

Teikoku Hormone Manufactory Co. Ltd, Tokyo) in $0.1 \mathrm{ml}$ of saline $(0.9 \%)$. The ovulatory process was induced $48 \mathrm{~h}$ later by an s.c. injection of 5 iu human chorionic gonadotrophin (hCG; Mochida Pharmacological Corp., Tokyo).

\section{Injection of RU486}

RU486 (RU38486: Roussel-Uclaf, Romainville, France) was dissolved in $70 \%$ ethanol $\left(10 \mathrm{mg} \mathrm{m}^{-1}\right)$, and a dose of $20 \mathrm{mg}$ $\mathrm{kg}^{-1}$ was administered s.c. $2 \mathrm{~h}$ before or at the same time as hCG injection. Progesterone, 10, 20 or $100 \mathrm{mg} \mathrm{kg}^{-1}$ (Proluton: Schering AG, Berlin) was given s.c. $2 \mathrm{~h}$ before $\mathrm{hCG}$ injection. The effects of RU486 were reversed by injecting $10 \mathrm{mg}$ progesterone $\mathrm{kg}^{-1}$ concomitantly with $20 \mathrm{mg}$ RU $486 \mathrm{~kg}^{-1} 2 \mathrm{~h}$ before hCG.

\section{Measurement of $3 \beta-H S D$ activity}

Rats were killed by chloroform vapour at the designated times. Ovaries were removed and stored at $-80^{\circ} \mathrm{C}$ until determination of $3 \beta-\mathrm{HSD}$ activity. $3 \beta$-HSD activity was assayed by the methods of Kuhn and Briley (1970), Okazaki et al. (1976), and Kawano et al. (1988) with a slight modification. Ovaries were weighed and homogenized in $0.25 \mathrm{~mol}$ sucrose $\mathrm{l}^{-1}$ at $0^{\circ} \mathrm{C}$ with a glass-glass homogenizer at a concentration of $20 \mathrm{mg}$ wet weight $\mathrm{ml}^{-1}$. The homogenates were centrifuged at $105000 \mathrm{~g}$ for $60 \mathrm{~min}$. The precipitates were rehomogenized at the same concentration as before, and centrifuged at $800 \mathrm{~g}$ for $5 \mathrm{~min}$. The supernatant fluids were used as the enzyme solution.
The assay mixture, which consisted of $40 \mu \mathrm{mol}$ glycine- $-\mathrm{NaOH}$ ( $\mathrm{pH} 9.4$ ), $0.9 \mathrm{mg}$ bovine serum albumin, $0.5 \mu \mathrm{mol}$ oxidized nicotinamide adenine dinucleotide $(\mathrm{NAD}+)$, and $50 \mu$ l enzyme solution, was preincubated at $37^{\circ} \mathrm{C}$ for $5 \mathrm{~min}$. The reaction was started by the addition of the substrate solution containing $5 \mu \mathrm{g}$ pregnenolone $\left(0.1 \mathrm{mg} \mathrm{m}^{-1}\right.$ in ethanol) in a final volume of $800 \mu$ l. The activity was determined spectrophotometrically by measuring the absorbance of NADH at $340 \mathrm{~nm}$. One unit of the enzyme activity was defined as the amount of enzyme producing $1 \mu \mathrm{mol} \mathrm{NADH}$. The intra- and interassay coefficients of variation were $4.3 \%$ and $9.6 \%$, respectively. The values were expressed as $\mathrm{mU} \mathrm{mg}^{-1}$ protein. The method of Lowry et al. (1951) was used for the protein determination with bovine serum albumin as the standard.

\section{Histochemical study of $3 \beta$-HSD activities}

Ovaries in control rats and RU486-treated rats were resected $4 \mathrm{~h}$ after hCG injection. Thin frozen sections $(14 \mu \mathrm{m})$ of ovaries were prepared with a cryostat (Sakura Seiki Co. Ltd, Tokyo), air-dried, and incubated at $37^{\circ} \mathrm{C}$ for $30 \mathrm{~min}$ with the reaction mixture containing $5 \mathrm{mg}$ dehydroepiandrosterone (dissolved in $0.2 \mathrm{ml}$ dimethyl sulfoxide), $15 \mathrm{mg}$ nitro-blue tetrazolium, $20 \mathrm{mg}$ $\mathrm{NAD}$, and $30 \mathrm{ml}$ Tris buffer $\left(0.1 \mathrm{~mol} \mathrm{l}^{-1}, \mathrm{pH} 8.0\right)$. The activities are represented as brown deposits of formazan, which were formed when $3 \beta$-hydroxysteroids were oxidized and then tetrazolium salts were coupled with hydrogen ion (Wattenberg, 1958).

The preovulatory follicles more than $300 \mu \mathrm{m}$ in diameter were studied $4 \mathrm{~h}$ after hCG injection. The number of these follicles was $33.6 \pm 2.1$ (mean \pm SEM) in a pair of ovaries, and this number was consistent with the number of ovulated ova in our rat models. The follicles were classified into three groups $(1+, 2+$ and $3+)$ according to the staining strength of enzyme activities in the granulosa cell layer.

\section{Steroid assays}

Blood samples were obtained by puncture of the inferior vena cava. Serum was separated and stored at $-20^{\circ} \mathrm{C}$ until assayed for progesterone and oestradiol. Both steroids were measured by radioimmunoassay kits (Sorin Biomedica, Saluggia, Italy). The sensitivities of the assays for progesterone and oestradiol were $0.10 \mathrm{ng} \mathrm{ml}^{-1}$ and $10 \mathrm{pg} \mathrm{ml}^{-1}$, respectively. The progesterone antiserum crossreacted with other steroids as follows: corticosterone, $2.5 \%$; deoxycorticosterone, $2.5 \%$; 17-hydroxyprogesterone, $2.0 \%$; and cortexolone, testosterone, pregnenolone, 20-dihydroxyprogesterone, cortisone, androstenedione, cholesterol, cortisol, dehydroepiandrosterone, oestradiol, oestrone, and etiocholanolone, $<0.25 \%$. The oestradiol antiserum crossreacted with other steroids as follows: oestrone, $0.7 \%$; oestriol, $0.55 \%$; 20 -dihydroprogesterone, $0.007 \%$; and cortisol, cortisone, cortexolone, corticosterone, cholesterol, progesterone, 17-hydroprogesterone, aetiocholanolone, pregnenolone, androstenedione, testosterone, dehydroepiandrosterone, and deoxycorticosterone, $<0.002 \%$. The intra-assay variations were $7.6 \%$ for progesterone and $3.4 \%$ for oestradiol. The interassay variations for progesterone and oestradiol were $8.5 \%$ and $9.0 \%$, respectively. 

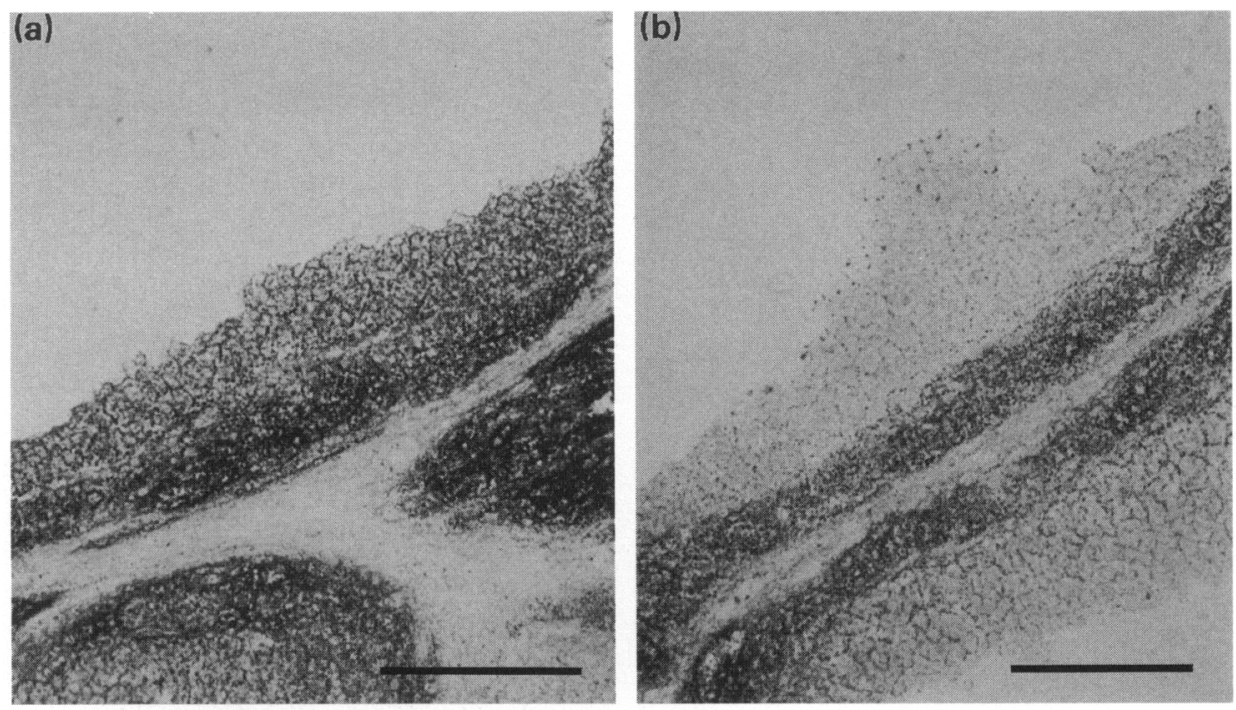

Fig. 2. Histochemical demonstration of ovarian $3 \beta$-hydroxysteroid dehydrogenase $(3 \beta-H S D)$ activity. (a) Strong $3 \beta$-HSD activities were observed in the granulosa and the theca cell layers $4 \mathrm{~h}$ after human chorionic gonadotrophin (hCG) injection. (b) $20 \mathrm{mg} \mathrm{RU} 486 \mathrm{~kg}^{-1}$ given $2 \mathrm{~h}$ before hCG injection inhibited the activities in the granulosa cell layer, but not in the theca cell layer, at $4 \mathrm{~h}$ after hCG injection. Bars represent $50 \mu \mathrm{m}$.

\section{Statistical analysis}

All data are presented as means \pm SEM. The significance of the differences in steroid concentrations and in enzyme activities between untreated groups and treated groups at any given hour during the ovulatory process was determined by Duncan's multiple range test after a two-factor (two-way) ANOVA of means of all experimental groups that could be paired across the $6 \mathrm{~h}$ of the study. In the other experimental groups, the significance of differences was determined by Duncan's multiple range tests after a completely randomized one-way ANOVA of the means of the groups. Chi-square analysis $\left(\chi^{2}\right)$ was used (Table 1 ). The threshold of significance was set at $P=0.05$.

Table 1. Histochemical study of effect of RU486 on $3 \beta$-hydroxysteroid dehydrogenase ( $3 \beta$-HSD) activity. Preovulatory follicles seen $4 \mathrm{~h}$ after $\mathrm{hCG}$ injection were classified into three groups $(1+, 2+$ and $3+)$ according to the staining strength of $3 \beta$ HSD activities in the granulosa cell layer. $20 \mathrm{mg}$ RU486 $\mathrm{kg}^{-1}$ given $2 \mathrm{~h}$ before human chorionic gonadotrophin ( $\mathrm{hCG}$ ) reduced the number of follicles showing high activity in the granulosa cell layer

\begin{tabular}{lccc}
\hline & \multicolumn{3}{c}{ Percentage of follicles } \\
& $\begin{array}{c}\text { Group 1 } \\
(1+)\end{array}$ & $\begin{array}{c}\text { Group 2 } \\
(2+)\end{array}$ & $\begin{array}{c}\text { Group 3 } \\
(3+)\end{array}$ \\
\hline $\begin{array}{c}\text { Control } \\
(35)\end{array}$ & $3^{\mathrm{a}}$ & 48 & $48^{\mathrm{b}}$ \\
$\begin{array}{c}\text { RU486 treated } \\
(54)\end{array}$ & $30^{\mathrm{a}}$ & 42 & $28^{\mathrm{b}}$ \\
\hline
\end{tabular}

The numbers in parentheses equal numbers of follicles analysed from five rats in control group and eight rats in RU486 group. $a, b: P<0.05$.

\section{Results}

\section{Effect of RU486 on ovarian $3 \beta-H S D$ activity}

In control rats, ovarian $3 \beta$-HSD activities increased significantly $(P<0.05) 4 \mathrm{~h}$ after the hCG injection (Fig. 1$)$. When $20 \mathrm{mg}$ RU486 kg ${ }^{-1}$ was administered $2 \mathrm{~h}$ before $\mathrm{hCG}$, the activities were significantly $(P<0.01)$ inhibited 4 and $6 \mathrm{~h}$ after hCG injection. However, when RU486 was administered at the same time as hCG injection, the activities showed no significant difference compared with those of control rats (Fig. 1).

\section{Histochemical study of ovarian $3 \beta$-HSD activity}

In control rats, strong $3 \beta$-HSD activities were observed in the granulosa and theca cell layers $4 \mathrm{~h}$ after hCG injection (Fig. 2a). When $20 \mathrm{mg}$ RU $486 \mathrm{~kg}^{-1}$ was administered $2 \mathrm{~h}$ before hCG, the number of follicles showing high activity in the granulosa cell layer was significantly $(P<0.01)$ decreased $4 \mathrm{~h}$ after hCG injection (Table 1). However, RU486 did not affect the activity in the theca cell layer (Fig. 2b).

\section{Effect of RU486 on serum steroid concentrations}

In control rats, serum progesterone concentrations rose significantly $(P<0.01)$ within $4 \mathrm{~h}$ after hCG (Fig. 3a). When $20 \mathrm{mg}$ RU486 kg ${ }^{-1}$ was given $2 \mathrm{~h}$ before $\mathrm{hCG}$, progesterone concentrations were significantly suppressed $4 \mathrm{~h}(P<0.01)$ and $6 \mathrm{~h}(P<0.05)$ after hCG (Fig. 3a). Serum oestradiol concentrations did not change significantly within $6 \mathrm{~h}$ after hCG (Fig. 3b). RU486 had no effect on serum oestradiol concentrations. 
(a)

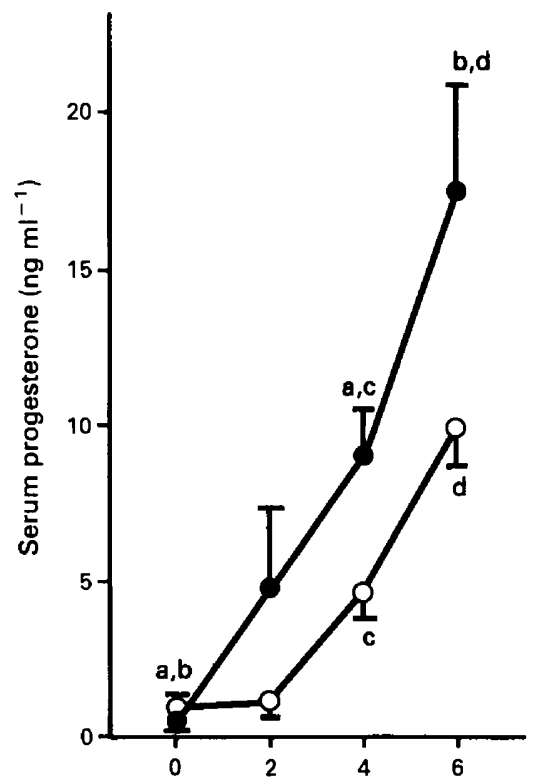

(b)

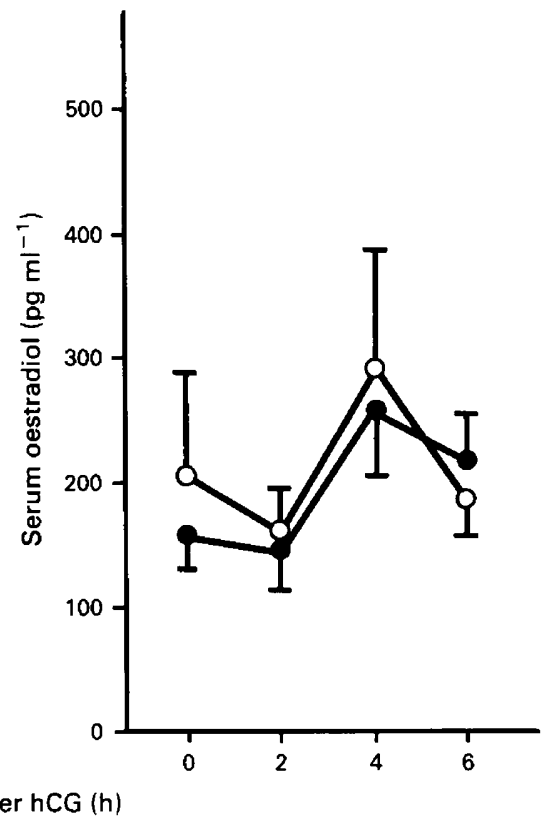

Fig. 3. Effect of RU486 on steroid concentrations in serum. Control ( $\mathrm{kg}^{-1}$ was given $2 \mathrm{~h}$ before hCG injection $\left(\mathrm{O}^{-} \mathrm{O}\right)$. Points with significantly $(\mathrm{a}, \mathrm{b}, \mathrm{c}: P<0.01$; $: P<0.05)$. Each point represents the mean $+\mathrm{SEM}$ from six rats.

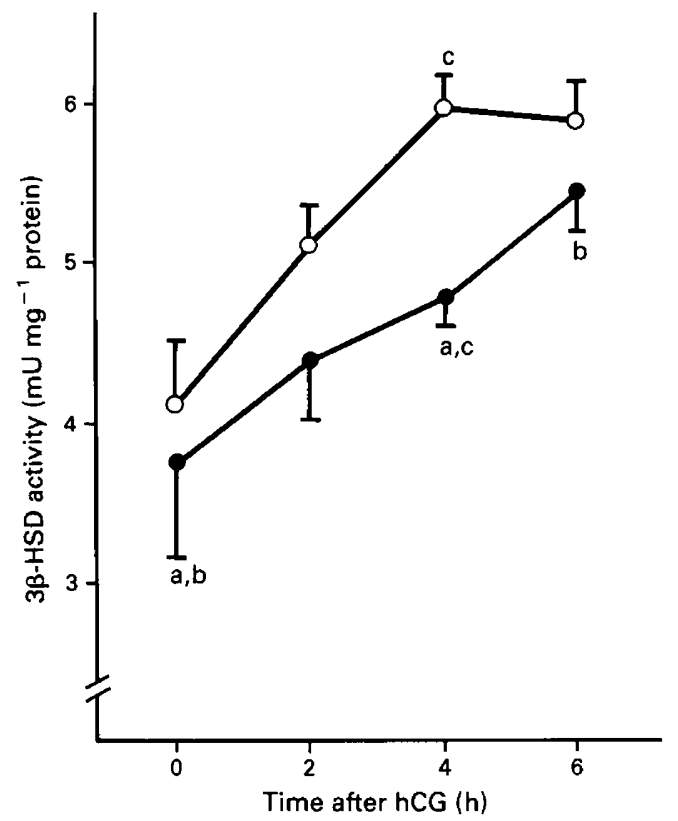

Fig. 4. Effect of progesterone on ovarian $3 \beta$-hydroxysteroid dehydrogenase $(3 \beta$-HSD) activity. Control $(-100 \mathrm{mg} \mathrm{kg}$ progesterone was given exogenously $2 \mathrm{~h}$ before hCG injection $(\bigcirc-O)$. Points with the same letter differ significantly (a: $P<0.05$; b, c: $P<0.01$ ). Each point represents mean \pm SEM from six rats.

\section{Effect of progesterone on ovarian $3 \beta$-HSD activity}

When $100 \mathrm{mg}$ progesterone $\mathrm{kg}^{-1}$ was exogenously administered $2 \mathrm{~h}$ before $\mathrm{hCG}$, ovarian $3 \beta$-HSD activities were

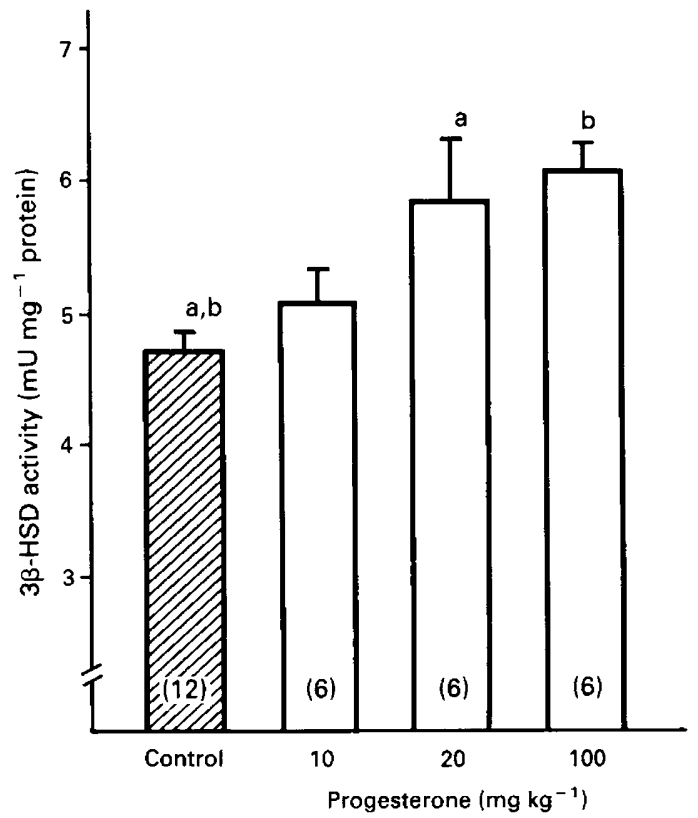

Fig. 5. Dose-dependent stimulation of progesterone on ovarian $3 \beta$ hydroxysteroid dehydrogenase ( $3 \beta$-HSD) activity. Graded doses of progesterone were given exogenously $2 \mathrm{~h}$ before human chorionic gonadotrophin (hCG) injection, and the activities were measured $4 \mathrm{~h}$ after hCG injection. Columns with the same letter differ significantly (a: $P<$ $0.05 ; b: P<0.01$ ). The numbers in parentheses represent numbers of rats.

significantly $(P<0.01)$ higher than control activities $4 \mathrm{~h}$ after hCG injection (Fig. 4). When graded doses of progesterone were administered $2 \mathrm{~h}$ before $\mathrm{hCG}$ injection, the activities were stimulated in a dose-dependent manner $4 \mathrm{~h}$ after hCG (Fig. 5). 
(a)

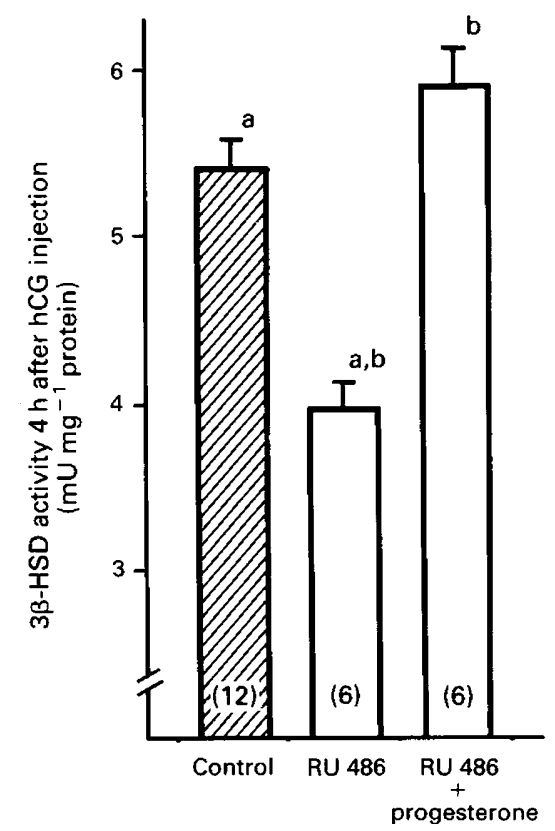

(b)

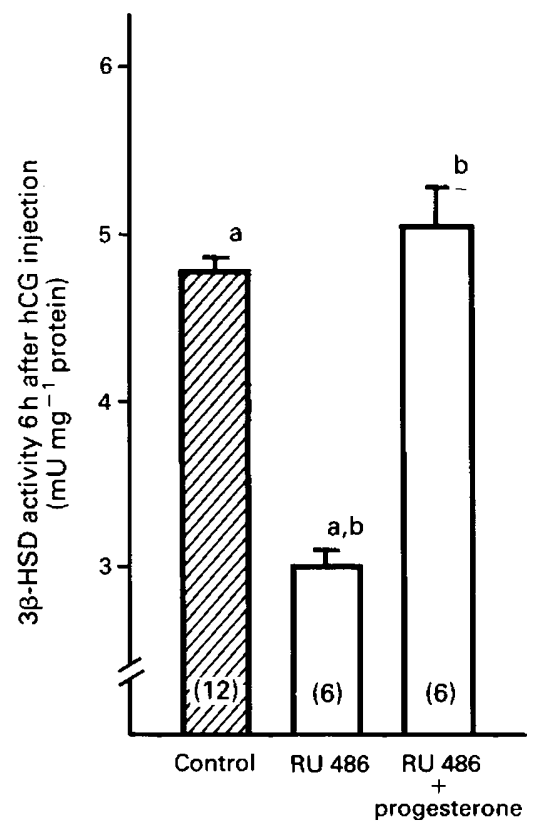

Fig. 6. Reversal of RU486 action by progesterone. $20 \mathrm{mg} \mathrm{RU} 486 \mathrm{~kg}^{-1}$ in presence and absence of $10 \mathrm{mg}$ progesterone $\mathrm{kg}^{-1}$ was given $2 \mathrm{~h}$ before human chorionic gonadotrophin (hCG) injection, and the activities were measured at (a) $4 \mathrm{~h}$ or (b) $6 \mathrm{~h}$ after hCG injection. Columns with the same letter differ significantly $(P<0.01)$. The numbers in parentheses equal numbers of rats.

\section{Reversal of RU486 action by progesterone}

Although $10 \mathrm{mg}$ progesterone $\mathrm{kg}^{-1}$ did not stimulate ovarian $3 \beta$-HSD activities (Fig. 5), the RU486-inhibited activities were recovered at 4 (Fig. 6a) and $6 \mathrm{~h}$ (Fig. 6b) after hCG injection by the concomitant administration of $10 \mathrm{mg}$ progesterone $\mathrm{kg}^{-1}$ with $20 \mathrm{mg}$ RU $486 \mathrm{~kg}^{-1}$ given $2 \mathrm{~h}$ before hCG.

\section{Discussion}

Although follicular development and steroidogenesis are primarily controlled by pituitary gonadotrophins, recent studies have demonstrated that autocrine and paracrine controls by steroid and peptide substances in the ovary are also involved (Franchimont et al., 1988). Oestradiol inhibits progesterone secretion in human granulosa cells (Veldhuis et al., 1983) and in bovine granulosa and theca cells (Fortune and Hansel, 1979). Progesterone inhibits the induction of aromatase activity in rat granulosa cells (Fortune and Vincent, 1983). These results from experiments performed in vitro suggest that steroids act as local mediators within the follicle to modulate production of other steroids and follicular development. Chakravorty et al. (1991) proposed that oestradiol may act as an autocrine or paracrine mediator of follicular development via the synthesis of a specific peptide factor in immature rat ovaries treated with diethylstilboestrol. Fanjul et al. (1983) suggested that progestins may exert an autoregulatory positive feedback action to enhance gonadotrophin-stimulated production of progesterone and $20 \alpha$-hydroxyprogesterone by cultured rat granulosa cells. In the present study, the autocrine regulation of progesterone production was examined by investigating the effects of progesterone and anti-progesterone RU486 on ovarian 3 $\beta$-HSD activity in rats in vivo. We showed that RU486 inhibits ovarian $3 \beta$-HSD activity, and that progesterone stimulates the activity and restores the RU486-inhibited activity. These results indicate that ovarian $3 \beta$-HSD activity depends, at least in part, on progesterone concentrations, and suggests that there is autocrine control of progesterone production in the ovary.

RU486 is a synthetic steroid that binds to progesterone receptors and acts as a progesterone antagonist (Herrman et al., 1982; Healy et al., 1983). Dimattina et al. (1986) reported that RU486 may directly affect ovarian progesterone production through the reduction of $3 \beta$-HSD activity by in vitro cultured human granulosa cells. Our in vivo experiments may support this finding. However, it is questionable whether RU486 directly and simply inhibits ovarian $3 \beta$-HSD activity in our experimental design because we used $20 \mathrm{mg} \mathrm{RU} 486 \mathrm{~kg}^{-1}$ in vivo, and up to $1 \mathrm{mmol} R U 486 \mathrm{I}^{-1}$ had no influence on $3 \beta$-HSD activity in our in vitro assay system. In addition, RU486 administration $2 \mathrm{~h}$ before $\mathrm{hCG}$ injection inhibited the activity at $4-6 \mathrm{~h}$ after hCG, and RU486 administration at the same time as hCG injection had no influence on the activity. Our previous data using epostane, a $3 \beta$-HSD inhibitor, demonstrated that epostane rapidly decreases ovarian progesterone concentrations whenever it is administered in vivo (Espey et al., 1990; Espey et al., 1991; Tanaka et al., 1991). It seems likely, therefore, that RU486 may inhibit $3 \beta$-HSD activity through the reduction of enzyme induction in the granulosa cells by acting as a progesterone receptor antagonist. The suggestion that RU486 
acts as a progesterone receptor antagonist in ovaries is supported by report of the presence of progesterone receptors and binding of RU486 to progesterone receptors in ovaries of diethylstilboestrol-treated immature rats (Schreiber et al., 1983).

Activity of $20 \alpha-\mathrm{HSD}$ increases after hCG stimulation in rat preovulatory follicles (Tsafriri and Eckstein, 1986) and RU486 stimulates ovarian $20 \alpha-\mathrm{HSD}$ activity in rat corpora lutea (Kawano et al., 1988). It is therefore possible that the decrease in hCG-stimulated progesterone production by RU486 is due to the decrease of $3 \beta$-HSD activity and the increase of $20 \alpha$-HSD activity. In this study we focused on $3 \beta$-HSD activity, and our histochemical observation that RU486 inhibited 3 $\beta$-HSD activity in the granulosa cell layer, but not in the theca cell layer, supports the suggestion that RU486 affects the process of induction of $3 \beta-H S D$. Fortune (1986) reported from studies using bovine theca and granulosa cell culture that theca $3 \beta$-HSD is less sensitive to inhibition by both oestradiol and epostane.

Ovarian progesterone concentration changes markedly during the first $4 \mathrm{~h}$ of the ovulatory process (Espey et al., 1990; Espey et al., 1991). This is the time when ovarian 3 $\beta$-HSD activity increases significantly. We have previously demonstrated that a small amount of progesterone during the first $4 \mathrm{~h}$ after hCG injection plays a critical role in ovulation through its effect on proteolytic enzyme activities, although progesterone production reaches a peak $8 \mathrm{~h}$ after hCG; in addition RU486 was shown to inhibit ovulation by inhibiting this action of progesterone (Iwamasa et al., 1992). The present study indicates that a small amount of progesterone just before hCG injection, together with hCG, seems critical for the expression of $3 \beta$-HSD activity. A small amount of progesterone just before and after the $\mathrm{LH}$ surge plays a regulatory role in the ovulatory process by modulating $3 \beta$-HSD activity and proteolytic enzyme activities.

In conclusion, the results suggest that there is autocrine regulation of progesterone production in the rat ovary, and that this autocrine regulation may play an important role in the ovulatory process.

\section{References}

Chakravorty A, Mahesh VB and Mills TM (1991) Regulation of follicular development by diethylstilboestrol in ovaries of immature rats Journal of Reproduction and Fertility 92 307-321

Dimattina M, Albertson B, Seyler DE, Loriaux DL and Falk RJ (1986) Effect of the antiprogestin RU486 on progesterone production by cultured human granulosa cells: inhibition of the ovarian $3 \beta$-hydroxysteroid dehydrogenase Contraception 34 199-207

Espey LL, Adams RF, Tanaka N and Okamura H (1990) Effect of epostane on ovarian levels of progesterone, 17ß-estradiol, prostaglandin $E_{2}$, and prostaglandin $\mathrm{F}_{2} \alpha$ during ovulation in the gonadotropin-primed immature rat Endocrinology $127259-263$
Espey LL, Tanaka N, Adams RF and Okamura H (1991) Ovarian hydroxyeicosatetraenoic acids compared with prostanoids and steroids during ovulation in rats American Journal of Physiology 260 E163-169

Fanjul LF, Ruiz de Galarreta CM and Hsueh AJW (1983) Progestin augmentation of gonadotropin-stimulated progesterone production by cultured rat granulosa cells Endocrinology 112 405-407

Fortune JE (1986) Bovine theca and granulosa cells interact to promote androgen production Biology of Reproduction 35 292-299

Fortune JE and Hansel $W$ (1979) The effects of $17 \beta$-estradiol on progesterone secretion by bovine theca and granulosa cells Endocrinology 104 1834-1838

Fortune JE and Vincent SE (1983) Progesterone inhibits the induction of aromatase activity in rat granulosa cells in vitro Biology of Reproduction 28 1078-1089

Franchimont P, Demoulin A and Valcke JC (1988) Endocrine, paracrine and autocrine control of follicular development Hormone and Metabolic Research 20 193-203

Healy DL, Baulieu EE and Hodgen GD (1983) Induction of menstruation by an antiprogesterone steroid (RU486) in primates: site of action, dose-response relationships, and hormonal effects Fertility and Sterility 40 253-257

Herrman W, Wyss R, Riondel A, Philibert D, Teutsch G, Sakiz E and Baulieu EF (1982) The effect of antiprogesterone steroid in women: interruption of the menstrual cycle and early pregnancy Comptes Rendus Academie des Sciences Paris (III) 294 933-938

Iwamasa J, Shibata S, Tanaka N, Matsuura K and Okamura H (1992) The relationship between ovarian progesterone and proteolytic enzyme activity during ovulation in the gonadotropin-treated immature rat Biology of Reproduction 46 309-313

Kawano T, Okamura H, Tajima C, Fukuma K and Katabuchi H (1988) Effect of RU 486 on luteal function in the early pregnant rat joumal of Reproduction and Fertility 83 279-285

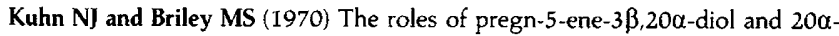
hydroxy steroid dehydrogenase in the control of progesterone synthesis preceding parturition and lactogenesis in the rat Biochemical Joumal 117 193-201

Lowry OH, Rosebrough NJ, Farr AL and Rondall RJ (1951) Protein measurement with the folin phenol reagent Journal of Biological Chemistry 193 265-269

Okazaki T, Okamura H, Motohashi T, Morikawa H, Yogo I and Nishimura T (1976) An enzymologic study of corpora lutea in early pregnant rats treated with abortifacient agents Fertility and Sterility 27 980-986

Rao IM and Mahesh VB (1986) Role of progesterone in the modulation of the preovulatory surge of gonadotropins and ovulation in the pregnant mare's serum gonadotropin-primed immature rat and the adult rat Biology of Reproduction 35 1154-1161

Schreiber JR, Hsueh AJW and Baulieu EE (1983) Binding of the anti-progestin RU-486 to rat ovary steroid receptors Contraception 28 77-85

Smith MS, Freeman ME and Neill J (1975) The control of progesterone secretion during the estrous cycle and early pseudopregnancy in the rat: prolactin, gonadotropin and steroid levels associated with rescue of the corpus luteum of pseudopregnancy Endocrinology 96 219-226

Tanaka N, Espey LL, Kawano T and Okamura H (1991) Comparison of inhibitory actions of indomethacin and epostane on ovulation in rats American Joumal of Physiology 260 E170-174

Tsafriri A and Eckstein B (1986) Changes in follicular steroidogenic enzymes following the preovulatory surge of gonadotropins and experimentallyinduced atresia Biology of Reproduction $\mathbf{3 4}$ 783-787

Veldhuis JD, Klase PA, Sandow A and Kolp LA (1983) Progesterone production by highly differentiated human granulosa cells isolated from preovulatory graafian follicles induced by exogenous gonadotropins and human chorionic gonadotropin Joumal of Clinical Endocrinology and Metabolism 57 87-93

Wattenberg LW (1958) Microscopic histochemical demonstration of steroid-33ol dehydrogenase in tissue sections Journal of Histochemistry and Cytochemistry $6225-232$ 